\title{
Design and Development of the Fashionable Qipao by Infliction of Hand Made Khadi Fabric
}

\author{
Nitish Chandra Roy ${ }^{1}$, Ronglei Luo', A. F. M. Fahad Halim², Chakma Arpan ${ }^{2}$ \\ ${ }^{1}$ Department of Fashion Design \& Engineering, Zhejiang Sci-Tech University, Hangzhou, China \\ ${ }^{2}$ Department of Textile Engineering, Zhejiang Sci-Tech University, Hangzhou, China \\ Email: ${ }^{*}$ roynitish123@outlook.com
}

How to cite this paper: Roy, N. C., Luo, R., Fahad Halim, A. F. M., \& Arpan, C. (2020). Design and Development of the Fashionable Qipao by Infliction of Hand Made Khadi Fabric. Art and Design Review, 8, 49-60.

https://doi.org/10.4236/adr.2020.81004

Received: January 9, 2020

Accepted: February 25, 2020

Published: February 28, 2020

Copyright $\odot 2020$ by author(s) and Scientific Research Publishing Inc. This work is licensed under the Creative Commons Attribution International License (CC BY 4.0).

http://creativecommons.org/licenses/by/4.0/

\begin{abstract}
Qipao is one of the most famous and most remarkable representatives of traditional Chinese dress which also can display the lasting appeal of oriental women. Qipao is not just a piece of clothing it is omnipresent in people's life. In this study, attempts were taken to redesign and develop Qipao by the integration of innovative design and selection of traditional Bangladeshi Khadi fabric. Firstly, the traditional Bangladeshi Khadi fabric was weaved by using handloom after that the pattern and design selection were done. Then the development of the fashionable Qipao by the infliction of handmade Khadi fabric was conducted. Furthermore, the market survey was conducted to evaluate the acceptance of redesigned Qipao among individuals. Survey results represent that, redesigned Qipao got the new consumer's attention and acceptability which will acquire and convey forward the conventional Qipao social meaning and aesthetic worth.
\end{abstract}

\section{Keywords}

Traditional Qipao, Khadi Fabric, Redesign, Modern Style

\section{Introduction}

Qipao, in Chinese, which can be written as 旗袍 (Qi's pao or Qi's robe) or 祺袍 (robe with luck) (Zhang et al., 2010; Yang, 2007). Qipao (qípáo) means "banner dress" or "banner gown", which refers to a style of a robe in the Qing dynasty (1644-1911) which was worn by Manchu women at that time (Ng, 2015; Heroldová, 2014). Qipao is a form-fitting traditional Chinese dress worn by the women. Qipao is also called "cheongsam" (Guo, 2014; Ching-Yu, 2011). The structure of Qipao which was worn by the Manchus was a long and loose-fitting dress. And that loose fitted garments were suited with their lifestyle. The Qipao 
dress got more popular across the mainland when China was conquered by the Manchu community at the Qing Dynasty. Cheongsam 長衫 is the Anglicized similar to the Cantonese pronunciation of the word for a long robe originally worn by men in the Qing dynasty (1644-1911) (Ng, 2018).

Qipao is not just a dress but also a representative of Chinese traditional dress. The main features of Qipao are a one-piece dress, fitted waist which can fully show the beautiful curve of a woman, the exquisite stand collar, oblique flap, the handmade button which forms the perfect combination of Qipao (Peng, 2016). Qipao is the representative of Oriental women's beauty which is a typical Chinese national traditional costume that is harmonious and unified inside and outside (Wei, 2017). For its artistic value and aesthetic characteristics Qipao is called an exotic dress in Chinese women's dress culture. Based on traditional Manchu women clothing the Qipao was designed by Han women (Qiao \& Tan, 2017). In the early $20^{\text {th }}$ century Qipao was designed with Western elements, which is representative of the typical combination of Eastern and Western cultures. The birthplace of modern Qipao is Shanghai which is a typical representative of oriental beauty. The "craftsmanship of Shanghai Qipao" shows the intangible cultural heritage of Shanghai (Sun \& Ma, 2011).

"Khadi" a handspun and handwoven fabric which is originated from the Hindi word "Khad" or "pit". Khad is a native name for the pit in which the weaver is seated at ground level and operates the loom with his legs and feet (Gupta et al., 2017). It is also probable that Mahatma Gandhi derived the name Khadi from khaddar, a traditional native word for homespun and handwoven cloth. That's why Khadi is also called another name Khaddar. Khadi was not just a symbol; it was a massive exercise in an organizational establishment, in forging networks, brand building, and ideological investment (Ramagundam, 2008). It is manufactured into two steps: manufacturing of yarn using "Charkha" (A spinning wheel) and manufacturing of fabric by yarn using loom (handloom) (Kumari \& Sing, 2019; Sharma et al., 2016). Khadi's self-texture is subtle due to hand spinning and hand weaving. Khadi is the only fabric where the texture is unique and distinctive that it cannot be duplicated due to the hand spinning of the yarn (Kaur \& Rathore, 2017).

Yan Lanlan et al. analyzed "how contemporary people perceive Qipao's design" (Yan et al., 2014). Jiang Yin Li studied "The design elements and contemporary use of china's Cheongsam" (Yin-Li, 2013). Wessie Ling investigated the "Fashioned way of the Qipao in 1930s China by Chinese Women" (Ling, 2017). Lushan Sun Studied the "70 Years of Fashion in the Chinese Dress" (Sun \& LeHew, 2013). Chui Chu Yang studied "how Qipao is defined by and has meanings for young women from Chinese and Taiwanese cultures" (Yang, 2007). Yuhong Liu studied "The tailoring method of Republic of China's Cheongsam" (Liu, 2016). Yi Wu analyzed the "Cheongsam design elements and influence on modern dress design" (Wu, 2015). They studied the meaning, evolution period, structure, pattern, color, trimming, tailoring method, pattern and style development process of Qipao and played an important role in modern time. 
In this study, endeavors were taken to redesign and develop traditional Qipao by the integration of innovative design and selection of traditional Bangladeshi Khadi fabric. Furthermore, the market survey was conducted to evaluate the acceptance of redesigned Qipao among individuals.

\section{Importance of Fashionable Qipao Design}

\subsection{Popularity of Qipao}

In the modern centenary, if contemporary Qipao needs continuity, advancement, and craze until be handed down from one genesis to another, the advancement and modernization are compulsory. Modern Qipao must have national emotions, traditional spirits, and the flavor of the times, to meet the needs of modern aesthetics. This is the need of the development of the times. Qipao can be called a type of high fashion. Nowadays Qipao got the high acceptance and popularity among the fashion-conscious women because it can show the beautiful curves of the chest, waist, and hips of beautiful women. Fashionable Qipao can fulfill the aesthetic beauty requirements of beautiful women by maintaining tradition and follow up the fashion trends that's why it is a hot and popular fashion costume among oriental women. Qipao targets on the legitimate fit between clothing and the body, the elementary and bustling construction, the delicacy and innate style, and the terse and eloquent line. Some fashion designers who like the classical oriental civilization will push Qipao into the global level, which brings a good future market. The stipulate of the family market chiefly mirror in the classical wedding dresses, while on other official moments come out to be fewer. While not at away, the distinct behavior makes people have a habit of wearing the various dresses for various functions, such as morning dress, day dress, evening dress, and so on, and there is a larger space for obligation and market potential for Qipao.

\subsection{Evolvement with the Modern Age}

In the integration atmosphere of multiracialism, diversity and multi-level artistic, there has never been the glister of "some style leading the trend for several hundred years" before several centuries in the domain of garment, metempsychosis, and equivalent of the assortment of styles is shown to the world, repeatedly come up new adventure shake the territory of fashion. The accelerated modification in the whole world makes people too many things to see, and let the human involvement the reverberation in the air from the appeal of fashion. Fashion is chic and prominent with the materialistic and dimensional, which makes it be more accessible signs of the times and made a guide and great brunt on consumers. The global fashion information through the clothing fiscal and commerce swap to the domestic, and the modernization of manufacture technology, the advancement of progress and the gimmick and use of new components boost the improvement of the homely clothing market on a large scale. The domestic attire is adaptable and coincides to develop, not only ingest and 
concentrate the basis of offshore civilization, but also absorb the classical presence of the tribe, take the reputation and fashion as a goal, and explore the familiar advancement.

\subsection{Comfort of Qipao}

With the change of people's working and living conditions in modern society, the pressure of work and life is greater, so people need to wear comfortable clothes, to bring some buffer to the tense life. Qipao is to highlight the body and fit the three-dimension, so that the wearer should always keep the tight posture of chest, waist, and hips in the process of wearing, while the high stand collar keeps the whole neck straight, restricts the flexible rotation of the neck and shoulders so that the whole body is always in a stiff state, which makes the clothing bring people tired in wearing, so Qipao is used in daily wear. In the design of the style, we should keep its graceful curve and reduce the limit to the body as much as possible to make it more comfortable to wear. The comfortable, easy to maintain and clean fabric is more accepted by modern people. With the acceleration of modern life, it is more convenient to put on and off the fashionable Qipao.

\subsection{Artistry and Individuation of Qipao}

After hundreds of years of baptism, the elements of Chinese traditional Qipao have become old and out of date in the modern era of seeking new and different things. The beautiful things are the eternal cycle of life, the endless existence of life, and the unremitting spirit, which is reflected in our continuous thinking about the essence of life. Personalized clothing must have beauty. It is the combination of the designer's artistic personality and the consumer's personality. Only a garment can finally realize its value. It is comprehensive rather than single. It combines the material, style, processing technology and decoration techniques of Qipao to create a Qipao form combining tradition and personality, artistry and traditional elements. Inject new life into the traditional Qipao.

\subsection{Diversification of Fabrics}

The development and change of fabric will always bring about the revolution of clothing. The first improvement of Chinese traditional Qipao is due to the input of new Western clothing materials. The input of fabric brings new patterns, new color combinations, and unprecedented fabric performance and texture. There are also new auxiliary materials and accessories, such as all kinds of new mechanism lace and buttons. With the development of new technology, the original manual processing characteristics of Qipao, such as inlaying and rolling, embroidery, are gradually weakening, which brings more area to Qipao fabric. The rich variety of modern clothing fabrics creates a broader area for the innovative design of Qipao. In the past, Qipao fabrics were mostly hand-painted and traditional decors. Modern fabrics of various new forms are very different from the past in color, pattern, and texture. From the performance of fabrics, they devel- 
op wrinkle resistance, wash ability, aging and quilting and padding that reflect the texture change. In addition, they also have the texture appearance of luminescent, metal, plastic and strange fabrics of glass, shiny stone, metal, and other attachments. The richness and diversity of fabrics bring new things to Qipao. The concept of "Qipao" will make Qipao develop in a comprehensive, and multi-dimensional direction, which will bring the characteristics of renewal, beauty, and comfort to Qipao. Qipao, as the representative clothing of the Chinese nation, has condensed the cream of the whole nation's clothing culture for thousands of years. The reason why it has spread so far has a lot to do with its "choice" and "change". While maintaining the connotation of traditional Chinese culture, it constantly absorbs the elements of fashion, making it a fashion style coexisting with tradition and fashion.

\section{Research Scopes for Fashionable Qipao Design}

\subsection{By Style Development}

The style of Qipao is changing with the change of the time. In the modern era, Qipao has got rid of the impression of flowing, loose and stereotype, and reinforced improvement of the body shape. The backdated old-fashioned waist of the Qipao gradually changed from the previous loose into tight narrow and the stand collar gradually turned into a modern and stylish low collar, which makes people's neck slender. The location of the buttons of Qipao is not confined to the armpit but moved to the left and right of the chest and back, which seems to be generous and the beauty of women's posture coming forward by getting shorter the length of Qipao. The style of Qipao can transform thousands of dignified or sexy style with a slight change (Zhang et al., 2010). Only the innovation in style and adding new elements, the Qipao could find its place and fascinate people's attention (Ding, 2016).

In this study, the style is inspired by Chinese fashion trends and Bangladeshi fashion trends. Here the A-line silhouette, Hourglass silhouette, Ballgown silhouette, Sheath silhouette, Straight column silhouette is used because they are popular and suitable dress silhouette for dress design. The flat pattern cutting method is used to develop a dress pattern. The Chinese mandarin collar is used because the Chinese mandarin collar is an important component of traditional Qipao. Some fashionable long sleeves are used which are looks like bell sleeves, puff sleeves, peasant sleeves, flounce sleeves, sleeves with a cuff which is most suitable for the current fashion trends and also for the Qipao and it also made them more fashionable and elegant. Single-sided large round front, Single-sided slanted front, Double-sided round-ba front, Double-sided angular-ba front is used in the chest area as an opening and for decoration as well. The dress length is long which reaches near to the ankle.

\subsection{By Fabric Development}

With the use of different fabrics in a Qipao, it can change the visual effects of the 
Qipao. We should choose different fabrics according to the uses because of Qipao has a very broad choice of materials. To get comfortable, beautiful, well-balanced coordination, prudent and generous effect on the daily wear Qipao it needs to choose a different color of fabrics according to age, color, shape, and other characteristics. For the short Qipao, lightsome, cool, beautiful and practical it can be chosen pure cotton printed shirting, yarn-dyed poplin, poplin, and even color, all kinds of yarn, printing horizontal satin, jacquard cloth, and other thin fabric in the summer season. It can be chosen synthetic or mixed textile products, such as the various flash silk, polyester silk, and a variety of thin fabrics in the spring and autumn season (Zhang et al., 2010). Its appearance keeps its smooth than the cotton fabric, gorgeously pleasing to the eye, in neither cold nor hot season is very suitable to wear although these fabrics contain moisture and poor ventilation.

In this study, Bangladeshi traditional handmade Khadi fabric is used to develop modern Qipao. Khadi which is a handwoven fabric has the quality of allowing more air penetration. Due to the thick and thin spaces created during hand spinning and for this reason, the hand-woven fabric forms air pockets in the fabric so this fabric breathes better and makes the fabric cooler, softer and more absorbent than highly uniform and compact machine-made fabrics. By adding breathability, it also increases the quality of the fabric which can keep the fabric cooler in summer and warmer in winter. The hand-woven fabric has a visible character and textural beauty. It can hold up very well to repeat laundering quality because Khadi cotton is a very strong fabric. Khadi cloth is unique and expensive because it's a handcrafted self-textured fabric. Some of Khadi fabric such as mulmul has a translucent quality. Khadi silk has richness and sheen quality that's why it is highly-priced fabric. Different places in Bangladesh produce different varieties of Khadi. Nowadays we found lots of dyed Khadi fabric that are dyed with a variety of colors and decorated by tied and dyed, block prints to give its beautiful surface. For this reason, Khadi is a suitable fabric for Qipao. Khadi fabric will give the Qipao the elegant looks with comfortability.

Cotton, silk, wool, and polyester made yarns are mostly used for Khadi fabrics. However, cotton yarn was used for Khadi fabric production for this study as the main raw material. These yarns were produced by hand-spun techniques. The weave structure of that Khadi fabric consists of the plain weave as their structure. The yarn count for the warp yarn of the fabric is $30 \mathrm{Ne}$ and the yarn count for the weft yarn is $24 \mathrm{Ne}$. Fabric GSM was $190 / 100 \mathrm{~cm}^{2}$. Table 1 shows the

Table 1. Weaving parameter.

\begin{tabular}{cc}
\hline Loom & Handloom \\
\hline Speed (rpm) & 100 \\
Reed speed (inch) & 50 \\
Weave & Plain \\
E.P.I & 44 \\
P.P.I & 40 \\
\hline
\end{tabular}


weaving parameters of Khadi fabric.

\subsection{By Innovative Application of Traditional Craftsmanship}

With the change of time, the pattern is also changing with the fashion and season. The pattern on the Qipao can reflect the design in a more fashionable way. Qipao with plate and intestines, wan word, flower pattern, watermark mainly reflects the meanings of good luck at the end of the Qing period. It was reflected the lacy adornment beauty in the 1920s when all the Qipao's collar, sleeve, lapel, and garment were decorated continuously with lace patterns. There was a more westernized pattern, like a check, broken pattern, and so on in the 1930s when the Qipao patterns were extremely rich, by western cultural influences. The patterns of Qipao are more and more exquisite, and more and more emphasis is on the role of "decorated" fashion after the evolution of a hundred years. In the modern era to ornament any of Qipao has a pattern as a "finishing touch", or fabric pattern, or a separate inlaid pattern, or using other fabric cutting patterns, or special embroidery pattern, or hollow pattern, various designs are designed (Zhang et al., 2010). The decorative Qipao patterns can be seen reflecting a variety of personality including, elegantly dignified, elegant and poised, beautifully generous, romantic and elegant and so on but there is no pattern on the Qipao that looks a bit stiff, solemn. The pattern of the fabric is consistent with the Qipao fabric and style of decoration.

In this study, the Bangladeshi alpana motif pattern is used for fabric pattern decoration. Alpana is a kind of folk art and a spontaneous expression of the artistic sensibility of people it is very much contemporary in feeling because it retains the experience of the community. It is mainly the womenfolk of the subcontinent who have kept the art alive in this part. They preserve contacts with ancient traditions and at the same time are bold enough to try out with new forms and new colors. They are aware of the changing moods of the seasons and their imagination thus marks the changing cycle of the year. The block printing method is applied for the surface ornamentation, which is a special method for fabric decoration. The application of Bangladeshi traditional alpana motif through the block printing technology changed the looks of the modern Qipao and it also gave modern Qipao an artistic, sexy and gorgeous look. Alpana which is a folk art in Bengal denotes colorful motifs, blessed art or painting which is done with hands. The paste of rice and flour is used as the paint or color on the different auspicious occasions in Bengal. The word Alpana is originated from the Sanskrit word alimpana, which expresses the meaning "to plaster" or "to coat with". Traditionally, it was drawn by the women of the house before sunset (Kar, 2015).

\section{Design \& Development Modern Era's Qipao}

As the representative of Chinese women's traditional dress, modern eras Qipao shows the unique charm and gentle and elegant quality of Oriental women. Noble and delicate texture, rigorous and smooth structure line, and beautiful 
color of the line express the women's softness and tenderness, and meticulous and sophisticated inlay, rolling, button, embroidery, and other decorative techniques, and finally represent a simple and concise modern Chinese dress Qipao (Li, 2015). The modern Qipao not only has the traditional culture breath but also conforms to the fashion trend. The traditional Qipao design elements are combined with modern high-tech fabrics and crafts for improvement. The works created can not only promote traditional culture but also meet the pursuit of modern women's personalities of fashion. It conforms to the aesthetic of the East and the present trend of the world.

In the design work, new embellishment artifice and also novel style such as some special silhouette were used which can truly represent the vogue design of Qipao. On material selection, Khadi fabric is the most fabulous fabric for Qipao. On the printing side, it is different from the traditional classical Qipao and the patterns were nonfigurative and exaggerated because Bangladeshi traditional Alpana motif is used for surface ornamentation of modern Qipao. In addition, the use of all of these materials plays a vital role in the style of the design and made the modified Qipao have a kind of different style.

Figure 1 shows the developed Qipao made by Traditional Bangladeshi Khadi fabric. The stand collar and straight pankou buttons, the silhouette like A-line, Hourglass, Ballgown, Sheath, Straight column silhouette and also the Bangladeshi traditional Khadi fabric and alpana motifs of this Qipao are the classic styles of Qipao, and with this some fashionable sleeves that combined western culture with eastern culture. The so-called fad is that we can use for reference, whether it belongs to the nation or the world.

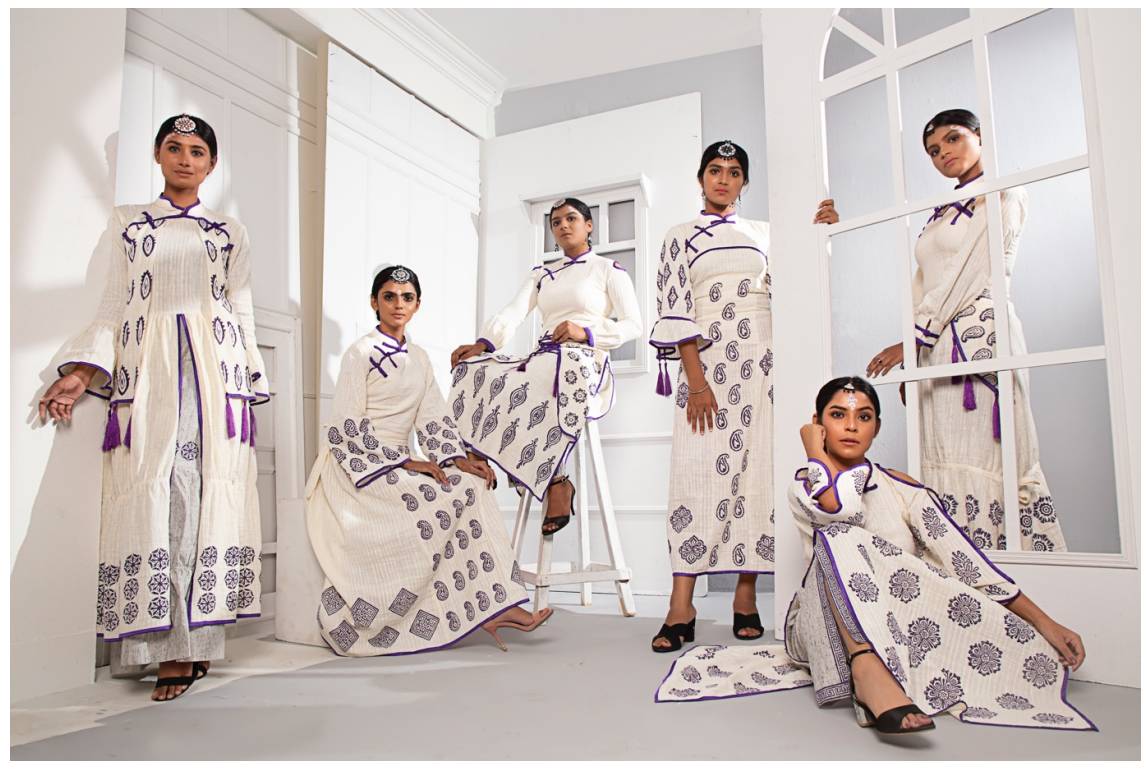

Figure 1. Khadi made modern Qipao.

\section{Market Survey for Developed Qipao}

Some of the basic questions were asked to analyze the acceptancy and the market 
demand for the developed Qipao's different style, it's different sleeve structure, the fabrics, and the surface ornamentation process. The questionnaire was used in Likert Scale method from "Highly Accepted", "Accepted", "Medium Accepted", "Lower Accepted", "Not Accepted", followed by an assignment 5, 4, 3, 2, 1 points. The data was conducted through an online survey method. In this survey, the participants were chosen as young because they are the ultimate customers for Khadi made Qipao. The online questionnaires were distributed among 100 people and 95 people responded, a total of 91 responses are valid other 4 responses are invalid to collect data. Finally, 91 valid respondent's data were prepared for analysis. Among them 62 were female and the 29 were male. Most of them were the student and their age level is $18-28$ years. About 68 respondents wanted to buy this Khadi made modern Qipao while the 23 respondents didn't want to buy this Khadi made modern Qipao. Figure 2 and Figure 3 represent different designs of Qipao and its consumer acceptance level.

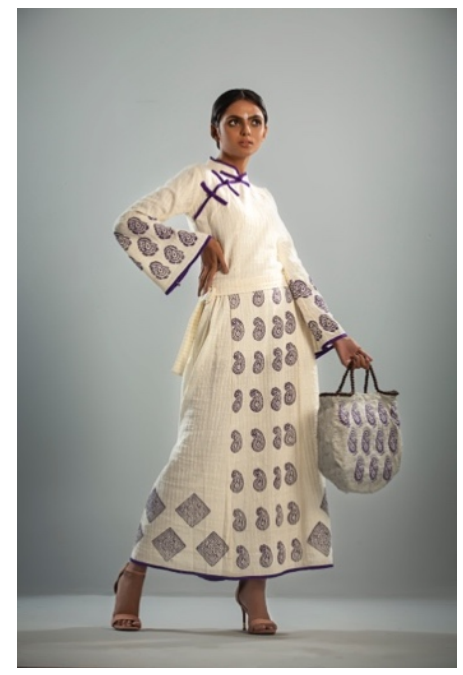

Design 1

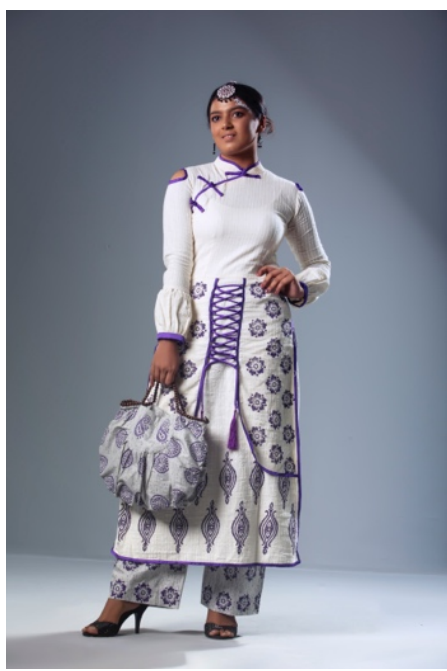

Design 4

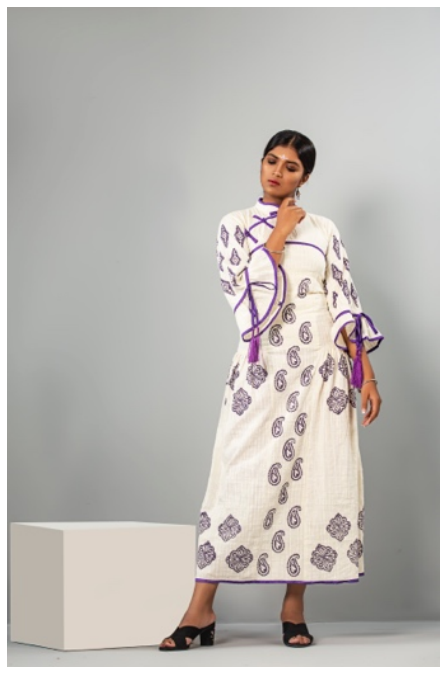

Design 2

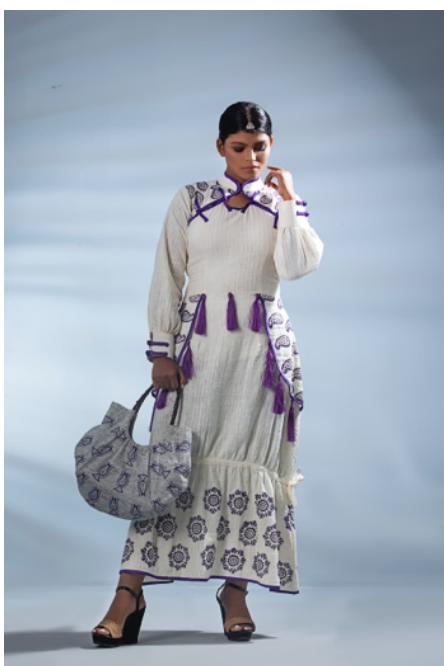

Design 5

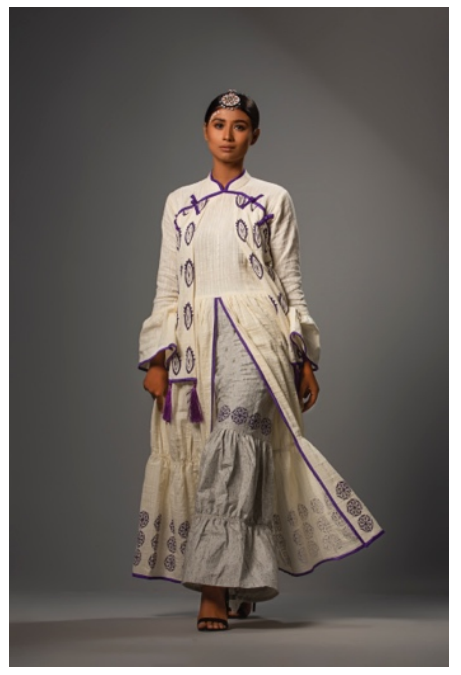

Design 3

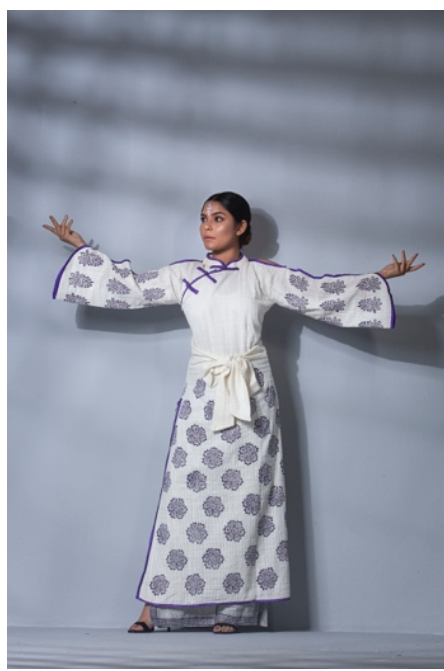

Design 6

Figure 2. Different designs of developed Qipao. 


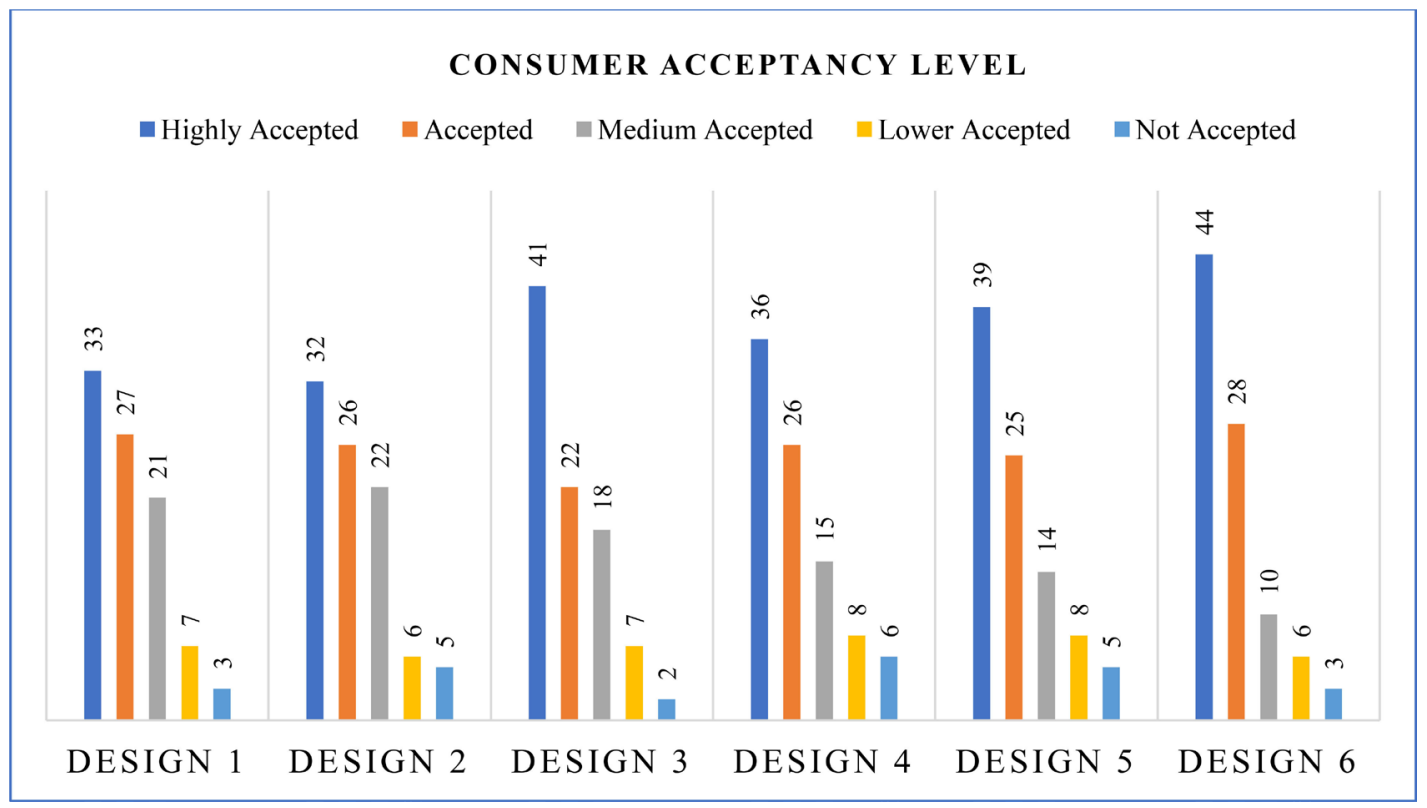

Figure 3. Consumer acceptancy level of different designs.

\section{Conclusion}

In this study, endeavors were taken to develop traditional Qipao by fabricating it with traditional Bangladeshi handmade Khadi fabric. Khadi fabric was made by a conventional handloom in order to retain its indigenous properties. The modernized Qipao's fabric has a distinct style and pattern characteristics; the color combination represents the traditional, eastern and western features. Furthermore, the market analysis was conducted which demonstrates that the acceptability of the redesigned Qipao is well within the acceptable limit. Fabrication of this redesigned traditional Qipao would improve its aesthetic and can fulfill the modern fashion goals by combing trends of a different culture.

\section{Conflicts of Interest}

The authors declare no conflicts of interest regarding the publication of this paper.

\section{References}

Ching-Yu, H. (2011). The Integration of Chinese Historical Costumes and Contemporary Women's Fashion: With Special Reference to the Shuitianyi. Ph.D. Thesis, Birmingham: Birmingham City University.

Ding, Y. (2016). On the Transformation and Popularity of the Cheongsam in Modern Time. In International Conference on Electronics, Mechanics, Culture and Medicine. Paris: Atlantis Press. https://doi.org/10.2991/emcm-15.2016.127

Guo, J. (2014). Aesthetic Characteristics of Shanghai Qipao in Chinese women's dress culture. In International Conference on Education, Language, Art and Intercultural Communication (ICELAIC-14). Paris: Atlantis Press.

https://doi.org/10.2991/icelaic-14.2014.128

Gupta, S., Rastogi, D., \& Mathur, R. (2017). Khadi: An Iconic Indian Cloth. Journal of 
Applied Sciences, 5, 267-278.

Heroldová, H. (2014). Allure of the Body: Chinese Qipao1.

Kar, R. (2015). Mirroring Aspirations: Älpanas in the Brata Rituals of Bengal.

Kaur, U., \& Rathore, H. S. (2017). Globalization, Youth and Khadi.

Kumari, T., \& Singh, D. R. (2019). Khadi: A Sustainable Fabric.

Li, N. (2015). An Interpretation of the Chinese Architectural Design Elements in Qing Dynasty's Costumes. In 1st International Conference on Arts, Design and Contemporary Education (ICADCE 2015). Paris: Atlantis Press. https://doi.org/10.2991/icadce-15.2015.70

Ling, W. (2017). Harmony and Concealment: How Chinese Women Fashioned the Qipao in 1930s China. In Material Women, 1750-1950 (pp. 209-224). London: Routledge.

Liu, Y. (2016). Even Small Skill Deserves Observing: Study on the Tailoring Method of Cheongsam in the Republic of China. Master's Thesis, Beijing: Beijing Institute of Fashion.

Ng, S. (2015). Gendered by Design: Qipao and Society, 1911-1949. Costume, 49, 55-74. https://doi.org/10.1179/0590887614Z.00000000063

Ng, S. (2018). Clothes Make the Woman: Cheongsam and Chinese Identity in Hong Kong. In Fashion, Identity, and Power in Modern Asia (pp. 357-378). Cham: Palgrave Macmillan. https://doi.org/10.1007/978-3-319-97199-5 15

Peng, Q. (2016). Aesthetic Expression of Chinese Elements in Modern Women's Clothing. In International Conference on Electronics, Mechanics, Culture and Medicine. Paris: Atlantis Press. https://doi.org/10.2991/emcm-15.2016.132

Qiao, N., \& Tan, Y. R. (2017). Talk About the Chinese Wedding Dress of Modern Women. DEStech Transactions on Social Science, Education and Human Science, (SEME). https://doi.org/10.12783/dtssehs/seme2017/18048

Ramagundam, R. (2008). Gandhi's Khadi: A History of Contention and Conciliation. Hyderabad: Orient Longman.

Sharma, M., Pant, S., \& Shakyawar, D. B. (2016). Development of Cotton: Wool Knitwears on Khadi System and Evaluation of Their Acceptability. International Journal of Home Science, 2, 9-12.

Sun, L., \& LeHew, M. (2013). 70 Years of Fashion in the Chinese Dress-Exploring Sociocultural Influences on Chinese Qipao's Hemline Height and Waistline Fit in 1920s-1980s. https://doi.org/10.31274/itaa proceedings-180814-622

Sun, M. Q., \& Ma, D. L. (2011). Ponders on the Silk Garment: Cheongsam Phenomenon. In Advanced Materials Research (Vol. 175, pp. 545-548). Zurich Switzerland: Trans Tech Publications. https://doi.org/10.4028/www.scientific.net/AMR.175-176.545

Wei, Y. (2017). Research on the Evolution of Cheongsam Style in the Republican Period and Its Contemporary Application. In 2017 International Conference on Culture, Education and Financial Development of Modern Society (ICCESE 2017). Paris: Atlantis Press. https://doi.org/10.2991/iccese-17.2017.120

$\mathrm{Wu}, \mathrm{Y}$. (2015). The Analysis of the Modeling of Cheongsam and the Influence on the Design of the Modern Dress. Master's Thesis, Shenyang: Shenyang University.

Yan, L. L., Bian, X. Y., \& Feng, M. Y. (2014). On the Contemporary Cognition of Qipao'Design. In Advanced Materials Research (Vol. 1048, pp. 201-206). Zurich Switzerland: Trans Tech Publications.

https://doi.org/10.4028/www.scientific.net/AMR.1048.201

Yang, C. C. (2007). The Meanings of Qipao as Traditional Dress: Chinese and Taiwanese 
N. C. Roy et al.

\section{Perspectives.}

Yin-Li, J. (2013). The Design Elements Analysis and Contemporary Use of the Republic China's Cheongsam. Master's Thesis, Hangzhou, Zhejiang: Zhejiang A \& F University.

Zhang, H., Jiang, X., \& Wang, L. (2010). Research on Fashion Design of Cheongsam. In Proceedings of Textile Bioengineering and Informatics Symposium. New York: TBIS Press. 